\title{
Students Perception on Physics Learning Interactions
}

\author{
Perdy Karuru ${ }^{1, *}$, Patta Bundu ${ }^{1}$, Anshari $^{2}$, Hamsu Abdul Gani ${ }^{3}$ \\ ${ }^{1}$ Department of Educational Science, Universitas Negeri Makassar, Indonesia \\ ${ }^{2}$ Department of Language and Literature, Universitas Negeri Makassar, Indonesia \\ ${ }^{3}$ Department of Engineering, Universitas Negeri Makassar, Indonesia
}

Received December 22, 2020; Revised March 10, 2021; Accepted March 23, 2021

\section{Cite This Paper in the following Citation Styles}

(a): [1] Perdy Karuru, Patta Bundu, Anshari, Hamsu Abdul Gani , "Students Perception on Physics Learning Interactions," Universal Journal of Educational Research, Vol. 9, No. 5, pp. 1044 - 1054, 2021. DOI: 10.13189/ujer.2021.090517.

(b): Perdy Karuru, Patta Bundu, Anshari, Hamsu Abdul Gani (2021). Students Perception on Physics Learning Interactions. Universal Journal of Educational Research, 9(5), 1044 - 1054. DOI: 10.13189/ujer.2021.090517.

Copyright $\bigcirc 2021$ by authors, all rights reserved. Authors agree that this article remains permanently open access under the terms of the Creative Commons Attribution License 4.0 International License

\begin{abstract}
This study aimed to determine how the students' perceptions of the interaction form of learning Physics in Junior High Schools. The research data sources were 104 teachers and 70 students who were taken by purposive sampling technique. Data collection techniques included observation, interviews, questionnaires, and documentation. Observations were made to describe the results of the analysis of teachers and students' behaviour in physics science learning. Interviews were conducted to determine interactions in learning Science Physics. Data about students' perceptions of learning interactions used a questionnaire. Meanwhile, the documentation technique is used to collect data from archives and documents related to this research. The data obtained through interviews were analyzed by data reduction, data presentation, and concluding, while data obtained through questionnaires were analyzed through editing, scoring, and tabulating. The study results found that the form of learning interaction desired by students in junior high school was learning that combined interactions between teachers and students, students with other students, students with media/learning resources, students with their groups, and groups with other groups. This can be seen from the strength of students' perceptions of three-way or more powerful interactions with a contingency coefficient value of $p=0.9313$. In addition, in this study, data obtained that of the 70 respondents there were $93.3-100 \%$ of students when three or more interactions were used in learning Physics in Junior High Schools. However, according to teachers and students, the use of one-way and two-way interactions is also essential to use during the learning process to deliver new concepts that are not yet / difficult
\end{abstract}

for students to understand, or the limited learning tools/media, or heterogeneous characteristics of students. The teacher has not correctly understood the steps of student-centered learning, such as the contextual approach and the constructivist approach.

Keywords Students' Perceptions, Interaction, Learning Physics Science

\section{Introduction}

Every learning activity always involves two active actors, namely teachers and students. The teacher, as a teacher who creates learning conditions for students that are designed deliberately, systematically, and continuously; while students as learning subjects are the ones who enjoy the learning conditions created by the teacher. The combination of teachers and students will develop a dynamic interaction in particular by utilizing media and teaching materials as the medium will affect the increase of the score obtained by students. In learning activities, teachers and students influence each other and provide input. That is why dynamic interaction must be lively activities, full of values, and always have a purpose [1].

In the learning process, interaction activities between teachers and students are quite dominant and in order the transfer of knowledge and transfer of values; components are compatible between one piece and another. This means that the elements that exist in learning activities adjust to each other to support the achievement of students' learning 
goals.

Learning is a process of interaction between teachers, students, and their environment to achieve a goal. This interaction can be in the form of one-way interaction (teacher-student), two-way interaction (teacher-student-teacher), and three-way or more interactions. In this process, students can gain experience from the teacher, their friends, learning resources, environment and so on. The experience gained by students will be consulted with the teacher. On the other hand, students are faced with a problem so that it can be overcome to solve the problem. The process of learning interaction like this will allow students to develop both mentally and intellectually.

The process of learning interaction activities carried out by the teacher in the classroom will affect the course of the learning process and is expected to be able to trigger teacher skills in carrying out interesting learning. In learning activities, the most important meaning is the creation of a good learning interaction between teachers and students. Teachers and students have a role in the process of interaction because teachers have a role as teachers and students as children who learn.

Physics natural science is one of the subjects given in junior high school, which contains aspects of the matter and its nature, energy and its changes, as well as knowledge of the earth and the universe. Through the Science of Physics subject, students are directed to be able to understand and apply knowledge (factual, conceptual, and procedural) based on their curiosity about the universe and its properties.

In the 2015/2016 academic year, the researcher as the Chair of the Committee at one of the junior high schools in Tana Toraja Regency has observed the interaction process carried out by teachers and students during the physics science learning process. Researchers see a phenomenon that occurs in the classroom, namely learning activities created by the teacher are more dominated by lecture methods and less varied with other learning models/approaches/strategies/methods. The tendency of the activities carried out by the teacher is focused on delivering material or students become objects during the learning process and not mutually playing a role during the learning process. Students only listen and listen well to the teacher's explanation and passive students so that students' learning interest and motivation towards learning is low. As a result, the average completeness of students' learning did not reach the Minimum Completeness Criteria at school ( $p>75 \%$ ). The achievement of learning completeness, of course, depends on the skills of the teacher in managing learning interaction activities. By using various forms of learning interaction, students will be very optimal in learning and have a high sense of enthusiasm and enthusiasm for learning.

Thus, the researcher sees that learning interaction is an essential element in the learning process, as an object of learning and teachers as the instructional designers. Through learning interactions that are divided into 5 (five) businesses, it allows perfect education or learning to be more effective, conducive and productive and can achieve satisfying learning outcomes. Based on the above problems, the authors were moved to examine further about the interaction in learning Physics Science in class through research entitled "Students' Perceptions of the Interaction of Physics Learning in Junior High Schools in Tana Toraja Regency". Therefore, the purpose of this study was to to find out the form of interaction of Physics Science learning that students want in junior high schools in Tana Toraja Regency.

\subsection{Perception}

According to [2], that perception is more psychological than just a sensory process, therefore several factors influence perception, namely selective attention, the characteristics of stimuli, individual values and needs, and previous experiences. Alternatively, it can be defined that perception is a process of observation that creates knowledge that is obtained, interpreted through vision, experience, planning, and belief to produce a view on something.

\subsection{Interactions in learning}

[3] in Rosarian Dirgantoro (2020) stated, "Interaction is the process by which people communicate with each other in thoughts and actions". This means that interaction is the process by which people communicate to influence each other in thoughts and actions. The interaction between teachers and students in learning is a process of communication, which is carried out reciprocally in conveying messages to students. The interaction referred to here is inseparable from the element of communication, which involves the communicator, communicant, message and media/learning resources components.

Essentially, learning is a process of increasing abilities both in the cognitive, affective and skills domains through interaction activities between learning elements. There are three elements of learning in question, namely teachers, students and media or learning resources. Suppose there is a perfect interaction between the three, that is what is called active learning. Perfect learning has at least five types of intensive interactions, namely: (1) interactions between teachers and students, (2) interactions between individual students and individual students, (3) interactions between students directly with media and sources; (4) Learning is interactions between individual learners and their groups, and (5) interactions between groups and other groups.

The meaning of three-way or more interaction in this study is the interaction between students and learning media/sources, individual interactions with other students, students with their groups, and group interactions with 
other groups. The form of interaction in three or more directions can be seen in Figure 1 below.

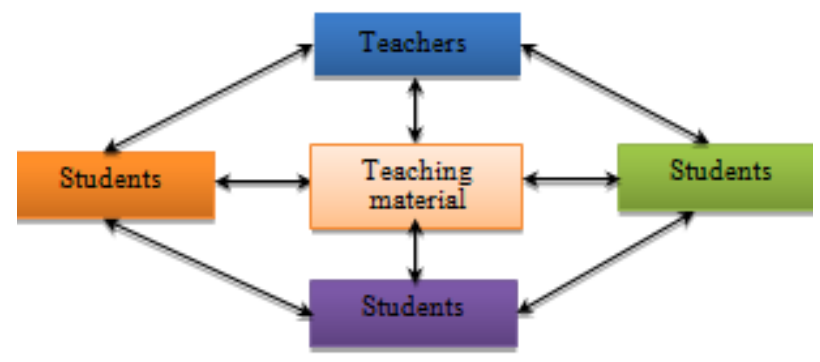

Figure 1. Three-Way Interaction or More (Multi-Directional Interaction)

\subsection{Nature of Physics}

Physics is one of the branches of science that underlies the development of advanced technology and seeks to describe and explain either natural laws or natural occurrences based on observable phenomena, directly or indirectly, which form the basis of the laws that move matter, energy, space. In addition, time. Physics is also a part of science that discusses the natural phenomena of science. Meanwhile, science itself is a collection of knowledge that is systematically arranged about natural phenomena, and its development is not only shown by facts but also by the emergence of scientific methods and scientific attitudes. Thus, it can be said that the Science of Physics includes three things, they are:

- Physical science products, namely all knowledge about natural phenomena that have been collected through observation. Products in the form of facts, concepts, principles, laws, and theories.

- The process of Physics science is usually called the scientific method, which is a combination of reasoning and empirical testing. The steps of the scientific method are problem identification, problem formulation, hypothesis formulation, conducting experiments, hypothesis testing, and drawing conclusions.

- Scientific values and attitudes, as long as carrying out the scientific method through the process of observation, experimentation and logical thinking, honest, objective, and communicative attitudes must be used in order to achieve the correct results of Physics Science.

\subsection{Study of Physics}

Physics subject in junior high school's objectives that students have the ability to: (1) increase belief in the greatness of God Almighty based on the existence, beauty, and order of His creation, (2) develop an understanding of various kinds of natural phenomena, concepts, and principles' science is useful and can be applied in everyday life, (3) develop curiosity, a positive attitude, and awareness of the interplay between science, environment, technology, and society, (4) conduct a scientific inquiry to foster abilities think, behave and act scientifically and communicate, (5) increase awareness to participate in maintaining, protecting and preserving the environment and communicating, (6) increase awareness to respect nature and all its regularities and (7) increase knowledge, concepts, and science skills as a basis for continuing education to next level.

Learning Science Physics will be humanistic if the teacher recognizes and places or treats students as subjects or individuals who have these characteristics, and the recognition is manifested in the learning process, which is to provide opportunities for participants to educate as widely as possible so that they can develop themselves so that their potential, personal, attitude develops towards a better or more perfect level. It is in line with the findings of [4] that multi-directional learning in science and physics learning will have an impact not only on learners' cognition but also on their behavior and attitudes in the learning process.

\section{Research Methods}

This research is classified as a descriptive study using two approaches, namely, a qualitative approach and a quantitative approach. The qualitative approach is used to obtain information about learning interactions obtained from the teacher as resource persons, and the quantitative approach is used to calculate the percentage of numbers from the results of the questionnaire regarding students' perceptions of interactions in learning Science Physics.

The population of this study was all junior high school students in Tana Toraja Regency as many as 2,750 people, while the sample was 70 people who were taken by purposive sampling technique. This technique was chosen because all junior high school student populations in Tana Toraja Regency are considered to have the same characteristics so that whoever becomes the respondent is considered to be able to represent the population.

In this study, researchers made observations without being directly involved. Through observations, researchers can describe the results of the analysis of the behaviour of teachers and students in learning Science Physics. In addition, interviews were also conducted to determine interactions in learning Science Physics. The form of interaction includes one-way interaction, two-way interaction, and three-way interactions or more. Meanwhile, the data about students' perceptions of learning interactions were used questionnaires. In addition, documentation techniques are also used with the aim of collecting data from archives and documents related to this research.

To obtain the validity of the data, the researcher carried out data validity checking techniques, namely (1) the technique of checking the degree of confidence (credibility) including the researcher was involved as an instrument, 
persistence of observation, triangulation, and referential adequacy, (2) transferability checking technique, and (3) dependability checking technique by way of dependency auditing.

After the data on students' perceptions in learning, the behavior of teachers and students in learning, and data taken from archives and documents are obtained then manage the data. The interview data obtained were analyzed through three streams, namely data reduction, data presentation, and drawing conclusions or verification. Meanwhile, the questionnaire data were analyzed by editing, suspension, and tabulating. Next look for the percentage of the questionnaire. The parameters for the interpretation of percentage values according to [5], namely:

$$
\begin{gathered}
0 \%=\text { None } \\
1 \%-25 \%=\text { Fraction } \\
26 \%-49 \%=\text { Almost Half } \\
50 \%=\text { Half } \\
51 \%-75 \%=\text { Most } \\
76 \%-99 \%=\text { Almost Entirely } \\
100 \%=\text { Entirely }
\end{gathered}
$$

The validity test of the instrument was carried out using the Pearson correlation method (correlation value $\geq 0.3$ ), while the reliability test used the internal consistency technique (Cronbach alpha coefficient $\geq 0.7$ ) with a confidence level of 0.05 .

\section{Research Result}

\subsection{Test the Validity and Reliability of the Instrument}

The results of the validity test of the Physics Science learning interaction questionnaire in junior high schools in Tana Toraja Regency showed that the twelve questions of the Physics Science learning interaction had a correlation value $>0.3$ with a confidence level of 0.05 as the limit value of an acceptable (usable) research instrument item. Therefore, it can be said that each item of the Physics Science learning interaction question item is valid and can be understood by all junior high school students. In other words, the Physics Science learning interaction instrument can be used to measure students' perceptions of the Physics Science learning interaction.

The instrument is said to be reliable and acceptable if the Cronbach alpha coefficient value is $\geq 0.7$, with a confidence level of 0.05 . The results of the reliability test of the perceptual instrument of junior high school students towards the interaction of physics science learning in junior high schools in Tana Toraja for each question item are presented in Table 1 below.
Table 1. Reliability Test Results

\begin{tabular}{|c|c|c|c|}
\hline Question Items & $\begin{array}{c}\text { Cronbach's } \\
\text { Alpha }\end{array}$ & $\begin{array}{c}\text { Value } \\
\text { Limit }\end{array}$ & Conclusion \\
\hline 1 & 0,760 & 0,7 & Reliable \\
2 & 0,812 & 0,7 & Reliable \\
3 & 0,779 & 0,7 & Reliable \\
4 & 0,760 & 0,7 & Reliable \\
5 & 0,815 & 0,7 & Reliable \\
6 & 0,810 & 0,7 & Reliable \\
7 & 0,779 & 0,7 & Reliable \\
8 & 0,758 & 0,7 & Reliable \\
9 & 0,780 & 0,7 & Reliable \\
10 & 0,798 & 0,7 & Reliable \\
11 & 0,712 & 0,7 & Reliable \\
12 & 0,828 & 0,7 & Reliable \\
\hline
\end{tabular}

Table 1 above shows that the Cronbach alpha coefficient value $>0.7$ (limit value) so that it can be concluded that the 12 instrument items are reliable and can be used to measure the perceptions of junior high school students towards the interaction of learning Science Physics.

Based on the results of the validity and reliability tests above, it can be concluded that the instrument of students' perceptions of the interaction of physics science learning in junior high schools can be used (correlation value $>0.3$ and Cronbach alpha coefficient value $>0.7$ ).

\subsection{Description of Learning Interaction}

In accordance with the data obtained through interviews and observations, the type of learning interaction in this study is divided into three parts, namely (1) one-way interaction, (2) two-way interaction, and (3) three-way or more interactions. Data on students' perceptions of learning interactions were analyzed using descriptive statistics in the form of percentages. The purpose of processing the data is so that the data obtained can provide meaning and explanation. The results of the questionnaire then entered into tabulation, which is the process of the questionnaire instrument data into percentage in below figures. In detail, the results of data analysis are presented as follows.

Teacher Data Analysis Carrying Out Learning Interactions

The results of observations on class VII teachers, class VIII teachers, and grade IX teachers in implementing Physics Science learning in class can be seen in Figure 2.

Figure 2 shows that of the ten teachers observed in each class, it turns out that all grade VII teachers (100\%) use a one-way interaction form, almost all (90\%) use two-way interaction, and half $(50 \%)$ use three-way or more interaction. Likewise, almost all grade VIII teachers in implementing Physics Science learning (90\%) use one-way interaction, almost all (80\%) use two-way interaction, and almost half $(40 \%)$ use three-way interaction or more. Meanwhile, almost all grade IX teachers (90\%) use one-way interaction and two-way interaction (80\%), and almost half (30\%) use three-way or more interactions. This 
shows that in general, physics science teachers in junior high schools in Tana Toraja Regency in implementing classroom learning use one-way and two-way interactions and only a few uses three-way or more interactions.

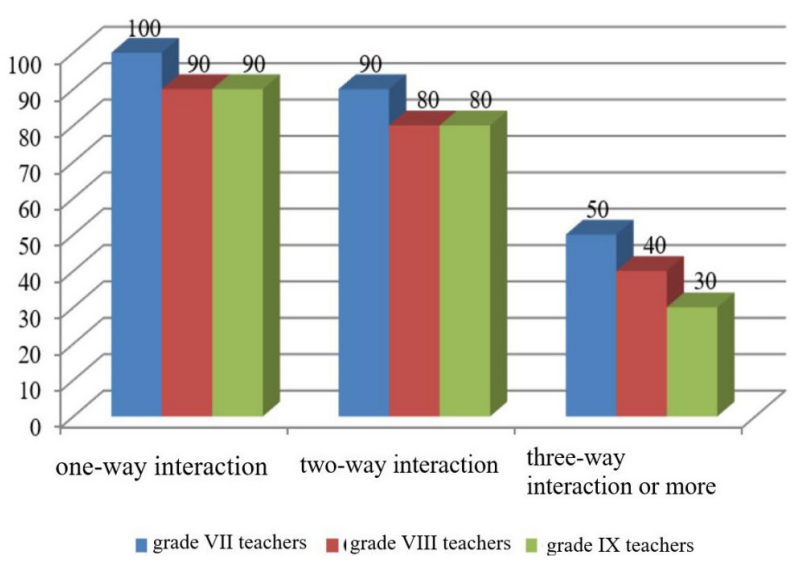

Figure 2. Teacher data in implementing Physics Science learning interactions

\section{- One Way Interaction}

The results of the data analysis on students' perceptions of the one-way interaction in the physics learning process in junior high schools in Tana Toraja Regency which were distributed to 70 respondents in detail can be seen in Figure 3 below.

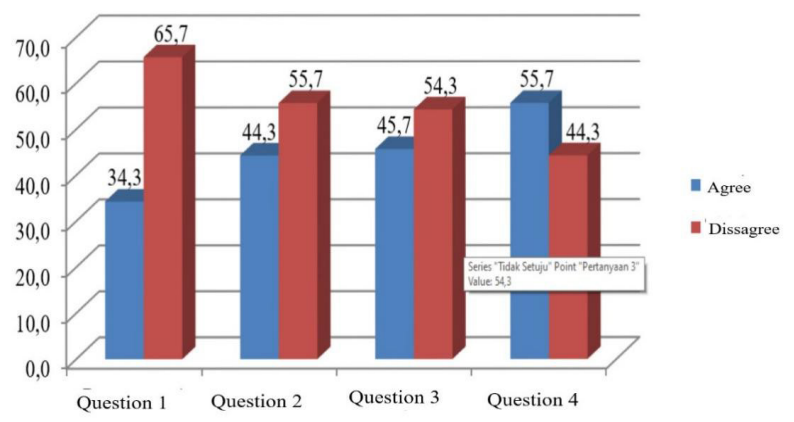

Figure 3. Percentage of one-way interaction questionnaire results

The data described in accordance with Figure 3 above can be presented as follows:

Questions 1. I like the teacher to explain the material with a lecture. Of the 70 respondents, almost half of $34.3 \%$ of students gave the opinion because they could more freely know the subject matter; the teacher explained it more clearly, easily understood new material or concepts. In addition, most or $65.7 \%$ of students gave different opinions because they were not given the opportunity to come up with ideas or ask questions.

Question 2. I like the teacher to explain, and the students are quiet, listening to the explanation well. Of the 70 respondents, almost half of $44.3 \%$ of students gave the opinion because they understood faster if the teacher explained, the material explained by the teacher was more detailed, and the teacher could find out the abilities of the students. In addition, most or $55.7 \%$ of students said they were not in agreement with the reason that they only heard and noted what the teacher explained.

Question 3. I like it when the teacher explains without giving opportunities to students to ask questions. Of the 70 respondents, almost half of $45.7 \%$ of students gave their opinion on the grounds that they are faster to understand or understand the subject matter, students are not noisy, and can concentrate. In addition, most or $54.3 \%$ of students gave different opinions on the grounds that students did not ask questions if something was not understood.

Question 4. I like to listen only when the teacher explains without being given the opportunity to come up with ideas. Of the 70 respondents, most or $55.7 \%$ of students gave an opinion on the grounds that they could concentrate and not make a headache, and nearly half or $44.3 \%$ of students gave different opinions on the grounds that they did not sharpen their brains, did not train their abilities, and tired of studying.

The data for the four questions above are in accordance with the data from the observations of 10 teachers in implementing physics science learning in class generally using a one-way form of interaction $(80 \%-100 \%)$, both class VII teachers, class VIII teachers, and class IX teachers. Thus, it can be concluded that the form of interaction used by science teachers in implementing learning is one-way and two-way interaction or generally using the lecture and question and answer method.

\section{- Two-Way Interaction}

The results of the data analysis on students' perceptions of the two-way interaction in the physics learning process at SMP, which were distributed to 70 respondents in detail can be seen in Figure 4 below.

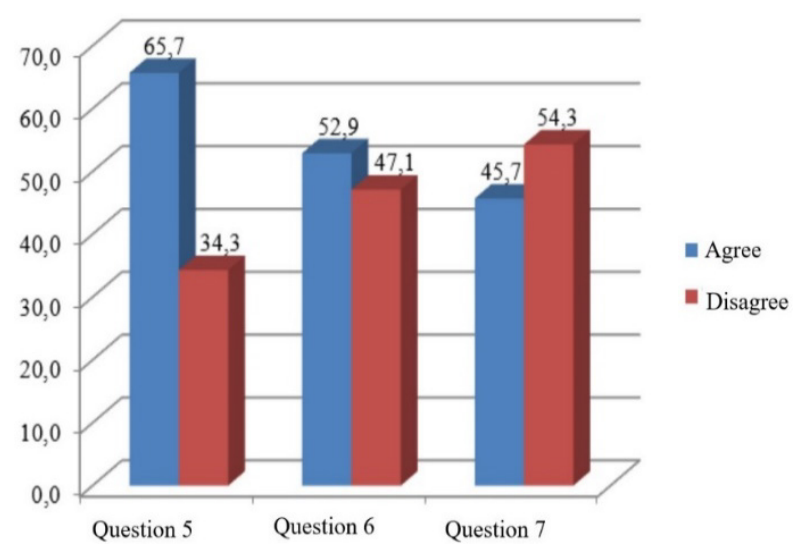

Figure 4. Percentage of two-way interaction questionnaire results

The data, according to Figure 4 above, can be explained as follows.

Question 5. I like to listen only when the teacher explains without being given the opportunity to come up with ideas. Of the 70 respondents, most or $65.7 \%$ of students gave the opinion on the grounds that they were 
always concentrated, not dizzy and not afraid to be asked. And almost half or $34.3 \%$ of students stated that they disagreed with the reason that they were easily sleepy, did not sharpen their brains, students would not be trained in their abilities, and made learning bored.

Question 6. I like it when the teacher explains the material and gives me the opportunity to ask questions. Of the 70 respondents, most or $52.9 \%$ of students gave an opinion on the grounds that the teacher can sharpen the students' brains, know better, want to test their abilities, students can be more active, and be brave. In addition, almost half of $47.1 \%$ of students gave different opinions on the grounds that they were confused, sometimes they didn't know what to ask, and not all students could ask questions.

Question 7. I like it when the teacher explains the material and involves students expressing opinions. Of the 70 respondents, almost half of $45.7 \%$ of students gave their opinion using two-way interaction in learning because students can know the core material that is important to understand, teachers can find out whether students have understood the material or not, sharpen the brain, even can make students dare to express opinions. Moreover, most or $54.3 \%$ of students gave dissenting opinions because they were dizzy, difficult, became talkative material, and did not know the material to be conveyed.

The data for the three questions are a description of the results of the analysis of two-way interaction learning in the form of questions and answers that can make the classroom atmosphere more lively and more dynamic than one-way interaction. It is possible that learning with two-way interaction occurs two-way communication or marked by feedback from the teacher even though there is even no communication between students. Learning conditions like this are commonly referred to as teacher-student-teacher interactions through communication. The data for the three questions are in accordance with the observation data on teachers in implementing physics science learning generally using two-way interactions, both class VII teachers (90\%), class VIII teachers ( $80 \%$ ), and only $40 \%-50 \%$ of teachers use the three-way interaction form.

\section{Three-Way or More Interaction (Multi-Directional)}

The results of the data analysis on students' perceptions of the three-way interaction or more in the physics learning process obtained from 70 respondents in detail can be seen in Figure 5 below.

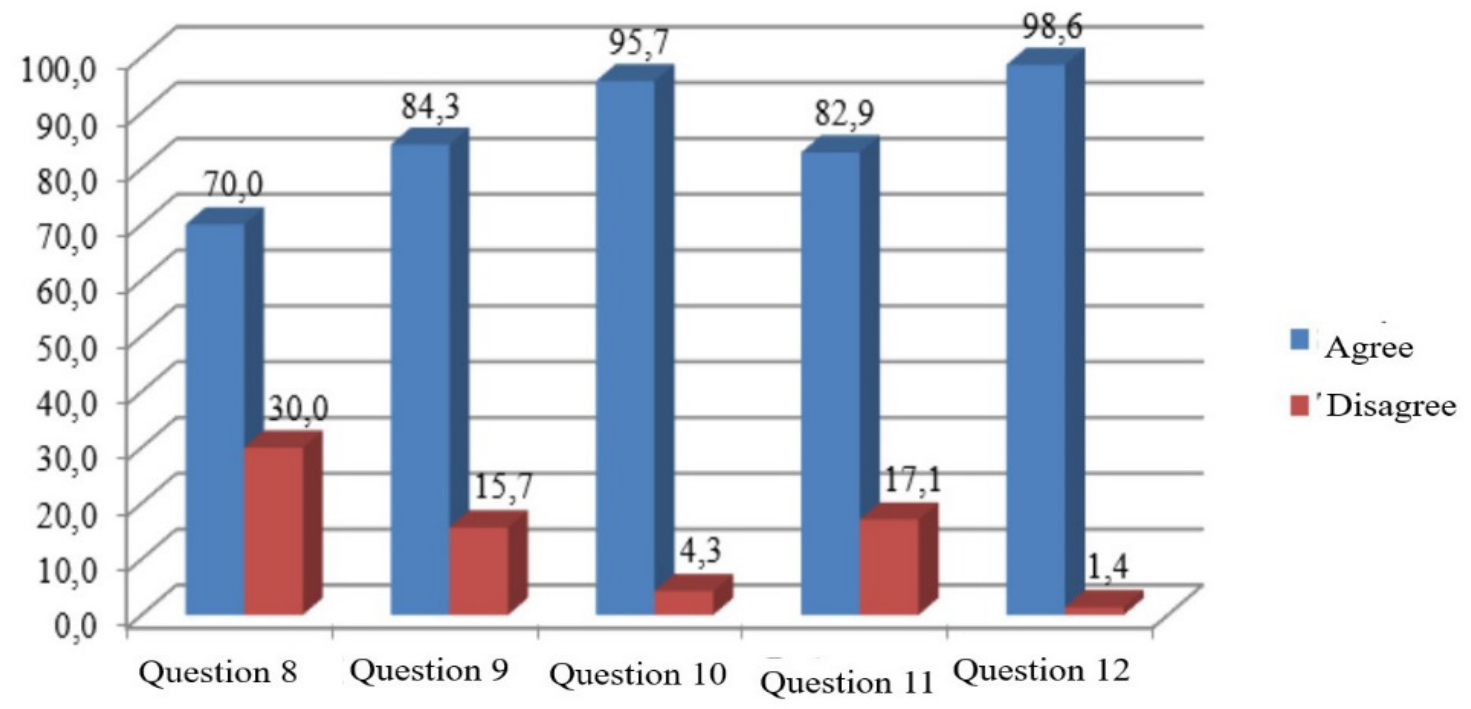

Figure 5. Percentage of three-way or more interaction questionnaire results 
The data in Figure 5 above about the three-way interaction in learning show that in general students give an agreed opinion if three or more ways of interaction are used in learning Physics Science. The results of the three-way or more interaction questionnaire data analysis in learning consisted of four questions, namely questions $8,9,10,11$, and 12. The explanation of the four questions can be presented as follows.

Question 8. I like it when the teacher uses media and learning resources during the learning process. Of the 70 respondents, $100 \%$ most of all $70 \%$ of students agreed that in learning the teacher uses media and learning resources on the grounds that the subject matter is easy to understand, the essence of learning is easy to know, making it easier to achieve goals, the learning is interesting, and can interact with friends and teacher. The learning media used by junior high school teachers in this study is an application that is displayed on a computer via PowerPoint. Meanwhile, learning resources are only limited to textbooks available in schools, and that too is very limited because one book is read by two students.

Question 9. I like it when the teacher uses the discussion method. Of the 70 respondents, $93.3 \%$ all of them then $84.3 \%$ of students gave the opinion if in physics science learning using the discussion method on the grounds that problems are easy to answer together with friends, more active in learning activities, making students think, high learning motivation, provide opportunities for students to practice expressing opinions, respect other people's opinions, and more quickly understand the material through peer explanations. And only a small proportion of $6.7 \%$, then $15.7 \%$ students gave different opinions on the grounds that sometimes it was difficult to answer problems with friends and were limited to expressing opinions because they were dominated by smart friends.

Question 10. I like to be given the opportunity to share with friends in learning. Of the 70 respondents, by $100 \%$ of them $95.7 \%$ of students gave their opinion on the grounds that they can share or share opinions with friends, are more courageous in expressing opinions/asking questions, are more active, and have good brains, and a small proportion of $4.3 \%$ of students gave different opinions on the grounds that they were ashamed of giving opinions or ideas to friends or teachers.

Question 11. I like to be given the opportunity to discuss in a group. Of the 70 respondents, by $96.7 \%$ of them $82.9 \%$ of students gave the opinion if in learning students were given the opportunity to discuss in groups on the grounds that problems are easy to answer, goals are easy to achieve, help each other, work together to discuss problems, and students actively involved in learning. And only a small proportion of $3.3 \% 17.1 \%$ of students gave different opinions on the grounds that the discussion was controlled by friends who were good at talking or smarter and the class atmosphere was noisy.

Question 12. I like to use discussions between groups and other groups in learning. Of the 70 respondents, by $100 \%$ all of them then $98.6 \%$ of students gave the opinion if the learning process used discussions between groups on the grounds that they could correct incorrect answers, respect friends' opinions, play an active role in learning, easy problems to answer, sharpen the brain, work the same, it is easy to find out mistakes in answering a problem, train the thinking process, practice submitting work reports, and be actively involved in solving problems. And only a small proportion of $1.4 \%$ of students gave different opinions on the grounds that only smart students played an active role in discussing questions.

\subsection{Chi-Square Analysis}

To determine the relationship between students' perceptions of learning interactions in one direction, two directions, and three directions or more, the Chi-Square formula is used. The results of the analysis of the three interactions can be seen in Table 1 below.

Table 2. Calculation of the chi-square of learning interactions

\begin{tabular}{|c|c|c|c|}
\hline Value & $\begin{array}{c}\text { One Way } \\
\text { Interaction }\end{array}$ & $\begin{array}{c}\text { Two-Way } \\
\text { Interaction }\end{array}$ & $\begin{array}{c}\text { Three-Way } \\
\text { Interaction }\end{array}$ \\
\hline Reliability & 6,524 & 5,799 & 30,808 \\
\hline
\end{tabular}

The data in table 1 above show that the one-way interaction value at a significant level of 0.05 with DB 3 is 6.524 , while $=7.815$. It means that there is no relationship between students' perceptions and one-way interaction in Physics Science learning. Likewise, for two-way interaction $=5.799$ at a significant level of 0.05 with DB 2, while $=5.991$. Thus $<$, or in other words, there is no relationship between students' perceptions and two-way learning interactions in mathematics learning. As for the three-way learning interaction or more $=30.808$ at a significant level of 0.05 and DB 4, while $=9.488$. This means $>$, meaning that there is a relationship between the students' perceptions and the interaction of three or more directions.

Meanwhile, to see the strength of students' perceptions of the three learning interactions, it can be seen in Table 2 below.

Table 3. Interpretation of the value of the contingency coefficient

\begin{tabular}{|c|c|c|c|}
\hline Explanation & $\begin{array}{c}\text { Contingency } \\
\text { Coefficient } \\
\text { Value (p) }\end{array}$ & $\begin{array}{c}\text { Significant } \\
\text { Level (DB) }\end{array}$ & Interpretation \\
\hline $\begin{array}{c}\text { One-way } \\
\text { interaction }\end{array}$ & 0,3585 & 3 & Weak \\
\hline $\begin{array}{c}\text { Two-way } \\
\text { interaction }\end{array}$ & 0,3245 & 2 & Weak \\
\hline $\begin{array}{c}\text { Three or more } \\
\text { directional } \\
\text { interactions }\end{array}$ & 0,9313 & 4 & Very strong \\
\hline
\end{tabular}

Based on the contingency coefficient data as in table 2 above, it is known that students' perceptions of the three-way interaction are very strong with $p$-value $=0.9313$. 
Meanwhile, students' perceptions of one-way interaction ( $\mathrm{p}$ $=0.3585)$ and two-way interaction $(\mathrm{p}=0.3245)$ were weak. Thus, it can be concluded that the strength of students' perceptions lies in the interaction of three or more directions.

\section{Discussion}

\subsection{Teachers Implement Learning Interaction}

The curriculum used in Junior High School throughout Tana Toraja Regency is KTSP (Education Unit Level Curriculum) for grade IX and Curriculum 2013 for grade VII and class VIII. The content of the KTSP curriculum used includes a number of subjects taken in grade IX. Local content and self-development are part of the curriculum content. Therefore, the KTSP SMP curriculum consists of 10 subjects, local content, and self-development. While the 2013 curriculum consists of 7 subjects, cultural arts, Physical Education, Sports and Health and crafts.

Although there are two curriculums used in junior high schools in Tana Toraja Regency, they are KTSP (Education Unit Level Curriculum) for class IX 2013 curriculum for class VII and for class VIII, almost all of the science teachers in implementing learning in the classroom $(80 \%-100 \%)$ use one-way interaction and two-way interaction, and nearly half $(30 \%-50 \%)$ use three-way or more interactions.

The data are in accordance with the results of interviews with several teachers who use the form of one-way interaction (interaction without feedback from students, for example, the lecture method) and two-way (learning interaction accompanied by feedback from students, for example, the question and answer method). They said that both forms this interaction are used on the grounds that the achievement of the material can be fulfilled in accordance with the demands of the curriculum and limited learning tools/media/resources, and the ability of students in heterogeneous. Students are reluctant to express opinions, and generally, students have not been able to interact with teachers or friends. While the form of three-way interaction or less is used experimental activities on the grounds of limited media and learning resources, and teachers have not mastered the steps of methods or models of student-centred learning such as scientific approaches. Constructivists, even though they have participated in the training or upgrading of the teaching methods organized by the Ministry of Education and Culture or other institutions. The lecture method is a one-way interaction pattern because the teacher's role dominates the activities during the learning process. In this case, the teacher is the action provider and the student who receives the action from the teacher. Whereas the question-and-answer method is a form of two-way interaction because of the reciprocity made by the teacher and students during the learning process, but there is no interaction between students.

From the results of the interview, a solution to the problem was obtained, namely (1) after the material was explained by the teacher through one-way interaction, then students were given assignments to work on individually, and then some students were asked to write down their answers on the board and correct them if the answer was still not appropriately, and (2) utilize learning tools/media around the school and duplicate teaching materials or replace the planned method with other methods.

\section{- One-Way Interaction}

Most of the students' responses to the four questions related to one-way interaction in learning (57.85\%) stated that they were not as one-way interaction. Likewise, if it is seen from the data about the relationship between students' perceptions and one-way interaction learning where the value at the significant level of 0.05 and DB 3 is 6.524 smaller than the value, namely 7.815 , which means that there is no relationship between students' perceptions and one-way interaction. Learning Science Physics. While the value of the contingency coefficient $p=0.3585$, which means that the strength of students' perceptions of learning with one-way interaction is weak. The data show that in principle, students in science learning Physics, one-way interaction is used. Students give the opinion that one-way learning students are not given the opportunity to express opinions/ideas or ask questions if there is still material that has not been understood, and only hear and record teacher explanations, do not sharpen their brains, do not train their abilities and are bored with learning. The opinions of these students illustrate that in the learning process students want to be actively involved, such as raising ideas / asking questions so that the material that has not been understood can be assisted by teachers or friends who already understand. In addition, students also hope that in learning, they can be given the opportunity to sharpen their brains, train and develop their abilities.

The response of the students above is contrary to the learning that is carried out by the science teacher in class. Almost all of the teachers in implementing learning in the classroom (80\% - 100\%) use one-way interaction learning, both class VII teachers, class VIII teachers, and class IX, teachers. The reason the teacher uses one-way interaction (for example the lecture method) is that the learning atmosphere becomes more orderly, the container explains new concepts that are not yet understood by students, the delivery of material is wider, the teacher can arrange priority material, and the teacher can monitor class conditions and higher material attainment. This finding is in line with the opinion of [7] that the lecture method is a way of delivering learning material with oral communication and is an example of one-way interaction. The lecture method is economical and effective for the purpose of conveying information and understanding. The dominance of a teacher when using the lecture method is 
very large so that students become passive. However, the classroom atmosphere is more orderly and conducive because students are only focused on the teacher as an action provider. Meanwhile, according to [8] the teaching method can be carried out by the teacher, first, to provide direction, instructions at the beginning of learning, second, limited time, while a lot of material or information will be conveyed. And third, educational institutions have few teaching staff, while the number of students is quite large.

This advantage becomes a consideration for the teacher to choose to use the lecture method as a one-way interaction in order to achieve learning objectives. Teachers in choosing learning methods must have careful consideration so that they can determine the method as an effort to achieve learning objectives. The results of interviews with respondents (Science Physics teachers) said that the lecture method as a one-way interaction besides having advantages also has disadvantages. Namely, students become more passive; the material controlled by students is limited; it makes students saturated; many students are sleepy and it is difficult to know the absorption power of students.

Based on the description above, it can be concluded that even though one-way interaction learning is not liked by students, on the other hand, this learning can still be used, especially in delivering new material/concepts which students have not understood and is quite broad in scope. It can make learning more orderly and conducive.

\section{- Two-Way Interaction}

Almost half of the students' responses to the three questions related to two-way interaction (42.37\%) stated that they were not in agreement. Likewise, if it is seen from the relationship between students' perceptions and two-way interaction, where the value at the significant level of 0.05 and DB 2 is 5.799 smaller than the value, namely 5.991, meaning that there is no relationship between students' perceptions and two-way interaction in physics science learning. While the value of the contingency coefficient $p=$ 0.3245 , which means that the strength of students' perceptions of learning with two-way interaction is classified as weak. The data show that in principle there are students if in learning two-way interactions are used because students are more concentrated, dare to ask questions, are not afraid to be asked, sharpen their brains, are more active, easily know the core material that is important to know, and the teacher can know the extent to which students have mastered the material. But on the other hand, almost half of the students do not agree if two-way interaction is used, such as only listening to the teacher's explanation without being given the opportunity to put forward ideas, and combining material explanations with giving the opportunity to ask students. In general, it can be said that in principle, students agree with the two-way interaction that combines the teacher's explanation with questions and answers and the classroom atmosphere is more lively and more dynamic than one-way interaction. It is possible that learning with two-way interaction occurs two-way communication or marked by feedback from the teacher even though there is even no communication between students. Learning conditions like this are commonly referred to as teacher-student-teacher interactions through communication. The data for the three questions are in accordance with the observation data on teachers in implementing physics science learning generally using two-way interactions, both class VII teachers $(90 \%)$, class VIII teachers $(80 \%)$, and only $40 \%$ $50 \%$ of teachers use the three-way interaction form.

The continuity of the two-way interaction in learning found in this study occurs because of the communication that comes from students to teachers or teachers to students. The teacher delivers the material and students respond to the material presented by the teacher. Learning activities in two-way interactions like this make the classroom atmosphere more interactive because of the reciprocity between teachers and students. Two-way interaction is the most effective and appropriate form of learning in order to increase students' motivation and learning outcomes. This statement was reinforced by junior high school physical science teachers both class VII teachers, class VIII teachers, and class IX teachers who said that two-way interaction learning could improve communication and opinions of two or more students and motivate students to learn.

Apart from going through questions to create a two-way interaction in learning, it can also be done by providing opportunities for students to ask questions. This can happen during the learning process, at the end of the discussion by the teacher, or during special meeting hours for that (response). Some teachers as respondents explained that two-way interaction in learning or it could be called the question-and-answer method had advantages, namely that students could develop courage and skills in answering questions or expressing opinions, and stimulating students to practice developing reasoning power.

One of the important elements in two-way learning interaction is asking. Asking plays a very important role, because well-structured questions with the right technique will increase student participation in learning activities, arouse students' interest and curiosity about the problem being discussed, develop students' mindsets, help students determine answers well, and focus students' attention on the problem being discussed. It is in line with the opinion of [9] that "science begins by asking questions and then seeking answers". This means that science begins by asking questions and then looking for answers. Therefore, in learning teachers use "closed" questions, or questions that have a number of correct answers, to test learners' understanding and retention of important information.

In this study, besides finding the advantages of two-way interaction in learning, it also has disadvantages. The drawback that exists in two-way interactions is the amount 
of time wasted because students need time to find the answers raised by the teacher. The existence of a target to pursue material that must be achieved by students, two-way interaction is not the main choice because the teacher needs to consider if the two-way interaction pattern is still used it results in a lot of material that must be achieved because of the lack of time. Likewise, what did some teachers as respondents that in two-way interaction learning a lot of time was wasted, learning time was limited, and it made students afraid because they were ready to answer questions, say.

\section{- Three-Way or More Interaction (Multi-Directional)}

Almost all of the students' responses to the five questions are related to three-way interaction learning $(82.36 \%)$. Judging from the value $=30.808$ at a significant level of 0.05 and $\mathrm{DB} 4$, while $=9.488$, this means $>$, meaning that there is a relationship between students' perceptions and three-way or more interaction. While the value of the contingency coefficient $p=0.9313$, which means that students' perceptions of learning with two-way interaction are very strong.

The strong relationship between students and three-way interaction learning or more shows that in principle; students in three-way or more interaction are used in learning. Students feel happy when learning media and learning resources are used, discussion methods, given the opportunity to share with friends, discuss in groups, and group discussions with other groups. However, teachers in implementing learning rarely use (only a small part, namely $30 \%$ - 50\% of students) three-way learning or more.

Through interviews, some students suggested that three-way or more learning is better and more complex in increasing the interaction and motivation of students to learn when compared to one-way interaction or two-way interaction. This is because in a three-way, learning or more students interact with media and learning resources so that they easily understand the material being studied. This is in line with Hamalik's opinion in [10] that the use of learning media in the learning process can generate new desires and interests, generate motivation and stimulation of learning activities, and even bring psychological influences on students. Also, in line with the opinion of [11] that "learning media is a tool that can function and be used to convey learning messages". This means that learning media is a tool that functions and is used to convey learning messages. This means that learning media is a form of the channel used to transmit messages, information or learning materials to stimulate students to learn.

In the learning process, the use of instructional media has the advantage that it can increase the interaction of students with other students and teachers both through groups and through discussions between groups. In addition, using learning media can help teachers convey messages, make it easier for teachers to convey messages, provide similarities to students about the material or solution to a problem, increase attention, interest, and direct students to learn.

Based on the description above, it appears that the use of media in learning interactions is very important. Therefore, the limitations of learning media in this study can be overcome by using simple learning media that are around the school, such as pictures or other media. Apart from being contextual, this media is also widely used in the learning environment and is well known to students and is even easy to operate by students.

Related to the results of the description of three-way or more interactions, it appears that in principle, learning with three or more (multi-directional) interactions can enable a more interactive learning process carried out by teachers and students compared to two-way interactions. With three or more directional interactions in learning, it will be able to increase the cooperation and learning activeness of students and help certain students who have learning difficulties. This is in accordance with the natural Sciences teacher's opinion that the advantages of interaction are three or more directions, namely creating teamwork, students being more active, making students aware that problems are easily resolved, and getting students to respect other people's opinions. In addition, teachers' activeness is also needed, such as providing guidance, motivation, stimulation and direction about what should be learned and how to learn it, and no less important to help students who experience learning difficulties.

To increase the activity of the learning process with this three-way interaction or more, the teacher needs to make the best possible planning and implementation based on the plans that have been made. In this way, it is hoped that it can boost the learning outcomes of students compared to other learning.

Three-way or more interaction in learning is a form of one-way communication, two-way communication, and three-way or more communication. Of the various forms of interaction will affect the method used by the teacher. This learning method is an important value for the sustainability of interaction as a medium of the learning process. The teacher has an important role in the learning process because the teacher should recognize students well through better interaction so that students can develop their abilities.

In addition to the advantages of three-way or more interaction, this learning has drawbacks as stated by the Physics teacher that in three-way interaction learning or more students get very limited information from the teacher, the class is too noisy, the presentation material is limited, and the discussion is only controlled by clever learners.

\section{Conclusion and Suggestion}

Based on the description of the research results described earlier regarding the students' perceptions of 
interactions in learning science and physics in junior high schools in Tana Toraja Regency, the authors can provide several conclusions including the form of learning interaction that students want during the learning process is learning that combines interactions between teachers and students, students with other students, students with media / learning resources, students with their groups and interactions between groups and other groups. Of the 70 respondents, there were $93.3-100 \%$ of seventh students who used three-way or more learning interactions in science learning physics.

Based on the above conclusions, the authors can provide several recommendations, namely:

1. Teachers should use varied learning methods according to how students learn so that learning creates various forms of learning interactions so that students are motivated to learn.

2. There needs to be a sense of belonging and knowing each other, namely teachers and students in an effort to create various forms of interaction (multi-interaction) learning to be more effective and conducive in every lesson.

This research can be used as a reference for continuing research on the development of valid, practical, and effective multi-interaction oriented learning models so that learning is centered on students so that students can develop their thinking power and in the end their learning outcomes will be better.

\section{REFERENCES}

[1] Zhang Y, Tiwari P, Song D, Mao X, Wang P, Li X, et al. Learning interaction dynamics with an interactive LSTM for conversational sentiment analysis. Neural Netw Off J Int Neural Netw Soc. 2021 Jan;133:40-56.

[2] Idi A, Safarina H. Sosiologi pendidikan: individu, masyarakat, dan pendidikan. 5th Ed. Jakarta: Rajawali Pers; 2015.

[3] Hurst B, Wallace R, Nixon SB. The Impact of Social Interaction on Student Learning. Read Horiz J Lit Read Horiz J Lit Lang Arts Langu. 2013; 52(4):25.

[4] Pica T, Berducci D, Holliday L, Lewis N, Newman J. Language learning through interaction: What role does gender play? Work Pap Educ Linguist WPEL. 1990;6(1):33.

[5] Horzum MB, Uyanik GK. An item response theory analysis of the Community of Inquiry Scale. Int Rev Res Open Distrib Learn [Internet]. 2015 Apr 15 [cited 2021 Mar 9]; 16(2). Available from: http://www.irrodl.org/index.php/i rrodl/article/view/2052

[6] Wasito H. Pengantar metodologi penelitian. Jakarta: Gramedia Pustaka Utama; 1992.

[7] Hasibuan JJ, Mudjiono. Proses Belajar Mengajar. Bandung: Rosdakarya; 1995.

[8] Yamin M. Strategi pembelajaran berbasis kompetensi. Jakarta: GP Press; 2007.

[9] Vale RD. The value of asking questions. Kozminski KG, editor. Mol Biol Cell. 2013 Mar 15;24(6):680-2.

[10] Arsyad A. Media Pembelajaran. Jakarta: Raja Grafindo Persada; 2009.

[11] Bovee CL, Thill JV. Business communication today. 8th Ed. New Jersey: Prentice Hall; 2005. 